\title{
Processing Limbukyu as Supporting Material in Producing Java Furniture
}

\author{
Joko Budiwiyanto ${ }^{1}$, Sumarno $^{2}$, and Siti Badriyah ${ }^{3}$ \\ 1 Lecturer at Interior Design Study Program, Faculty Fine Art dan Design, Indonesia Institute of the Arts in Surakarta \\ 2 Lecturer at Interior Design Study Program, Faculty Fine Art dan Design, Indonesia Institute of the Arts in Surakarta \\ 3 Lecturer at Interior Design Study Program, Faculty Fine Art dan Design, Indonesia Institute of the Arts in Surakarta
}

Email: jkbudiwiyanto@yahoo.com

\begin{abstract}
The waste of wood powder produced from timber industry has not been utilized optimally, its use is limited for firewood alone. Through the process by formulating with other materials can produce new materials that can be used as a supporting material of furniture industry. This study aims to make a formulation of the utilization of waste wood powder (limbukyu, Javanese) teak as a supporting material of furniture manufacture. This purpose is taken considering the utilization of wood raw materials in Indonesia increasingly scarce. The government also appealed and directed to be more efficient in the utilization of wood materials. Innovation through re-use by reusing useless materials becomes more useful and environmentally friendly is an option. The selection of materials with the concept of re-use will be more advantages, in addition to unique, and efficiency, waste wood powder can be used as a substitute for the main raw materials of teak wood. To achieve the goal required the research methods by using experiments. Data sources are in the form of artifacts, literatures, and informants. The analytical technique uses inter case analysis. The results showed that the use of wood powder waste as an interior supporting material, especially furniture source on the culture of archipelago, such as the backrest, the top of the table, feature wall, wall lamp, ornament, standing lamp can be produced by adjusting the material characteristics.
\end{abstract}

Keywords: Waste wood powder, re-use, furniture, and Java styles.

\section{Introduction}

The scarcity of wood raw materials in Indonesia increasingly worrying we think about the future of our next generation of this need, even the question arises that makes the more sad "How is the balance of nature after human intervention in exploiting it? As long as their needs are not many, still under natural productivity, then the tree will not become scarce or rare. However, if trees are logged in large quantities and continuously without sufficient effort to replant them, it is certain that one or several types of trees are becoming scarce. Since the need for these raw materials for the furniture industry is high.

Furniture industry sector is a vital driving force of development today, commodities in this field take a dominant role for the pace of the economic framework in Indonesia. The large number and rate of population growth in Java Island has implications for domestic demand for wood consumed, among others, as construction materials, household appliances, and timber industry needs for export markets. For several years most of the needs are met by natural wood coming from outside Java. To meet the existing needs can not be met by timber production from forest areas in Java Island which is managed by Perum Perhutani, but also timber outside Java and people's garden. Central Java province is the center of national furniture industry where most of its products are intended for export, so that it is a large foreign exchange earner for the region and the largest foreign exchange earner for wood furniture industry nationally. The value of Indonesian furniture exports in 2016 reached US \$ 2.8 billion, jumping $40 \%$ from the 2015 estimate of US $\$ 2$ billion. Export volume is estimated growing in $30 \%$. Meanwhile, wood furniture exports in 2012 reached US $\$ 1.24$ billion with a volume of 461.578 million $\mathrm{kg}$. That figure grew to US $\$ 1.56$ billion with a volume of 531.585 million $\mathrm{kg}$ in 2013. [1]

Currently, the condition of timber industry in Central Java, especially wooden furniture products, has a shortage of wood raw materials. The potential of natural resources which are increasingly being sought to be explored, exploited to meet the need for raw materials for wood-based furniture industries increasingly sought by the government and the private sector, sometimes less consider in conservation, even illegal logging practices are difficult to know because the more creative Wood hunters. Therefore sawmills and wood processing industries that produce wood waste which in the form of spelled (sebetan), small pieces of geometric shapes, tatal (waste of wood chopping), and sawdust need to be processed into raw materials supporting 
the furniture industry. From some of the waste from the sawmill and wood processing industry, there is a potential for waste that can be reused, one of which is sawdust.

Waste wood powder or sawdust (Limbukyu) is a sawmill waste industry. In some areas scattered sawmills that produce daily waste of sawdust. The company did not throw it away, so that the day by day the waste was mounting. This condition can be an unpleasant sight. Efforts to use it to have economic value, some of which sell as alternative fuel economic value, but not yet maximally as a solution of economic and environmental problems. The facts, on the field sawdust often raise problems in the handling of which the situation is allowed to rot, stacked and burned which all have a negative impact on the environment so that preventive efforts are needed once.

ISI Surakarta as an art university respond by presenting creative economic products through how to use them into value-added products with applicative and populist technology, so the results are easily socialized to the public. Waste to product processing is waste processing into raw materials or new products with economic value. In its management, waste to product must apply the principles [2]: reduce (reduce the use of wood materials is to reduce and prevent deforestation due to illegal logging), reuse, recycle, reducing cost, energy-saving, eco-efficiency (waste sawdust processing is expected to have a positive impact on the environment). Alternative solutions that can be taken is to use it into value-added products with applicative and populist technology, so the results are easily socialized to the community and immediately applied to conserve natural resources, especially wood raw materials.

Based on the explaination above, it is necessary to have a concern from various parties. Good cooperation for the furniture industry, stakeholders and academics, especially art institute with the capacity to contribute in problem solving and synergize in the continuity of mutual symbiosis. Contribution of science, skill and development of furniture component design is very meaningful for the progress of furniture industry spread in Indonesia. The creative economy is an important issue worldwide, especially in the context of wealth creation and prosperity. In further examined, the scope of creative economic activities included in the creative industry shows that the arts and art-related fields are the backbone of the creative economy (almost 50\% are directly related to the arts such as art and antique market, craft and design) . [3] From that social reality, it is very urgent on having research proposal related to the potential study of Limbukyu in the form of action research. The substance of this research activity is in order to explore the shape of the design based on Javanese traditional art culture in accordance with the character of Limbukyu which has a unique selling point on the market. The optimistic of this activity is expected to be able to answer the problem of efficient use of wood raw material. With the large amount of Limbukyu, various design innovations with the nation's character image can be created that will be a valuable skill to Limbukyu's potential. The analysis of the design form that has a unique selling point is more directed to the traditional character of Java which then formulated in a form of design that is able to penetrate the market which can give affective meaning. [4] The absolute monarchy system of the Mataram kingdom is a powerful system in determining the color and "javanese" cultural figure of Java. [5] The richness of visual art and the diversity of cultures in Indonesia makes the inspiration of the design form that interesting for buyers, the sensitivity of seeing the market and the creativity in designing the contextual furniture components which contain semiotics [6] as a sign that is capable on characterizing the nation and recognizing the period Visual products are produced. Moreover, as a global preventive step is getting stronger foreign products pushed with a variety of features that offer modernity in the realm of life style, which evolutively ripped the love of local products. Thus some knowledge of potential Limbukyu design will be the enlightenment of some aspects of Indonesian society life and requires serious attention and care by all parties. Therefore, the presence of Limbukyu design can serve as a lifesaving factor for the preservation of culture, natural resources and environment. This study aims to 1). Identify the character of furniture design from Limbukyu material that is adaptable to the character of the material with the tradition theme 2). Describes the production process of Limbukyu design, related to the material composition, print technique, and finishing.
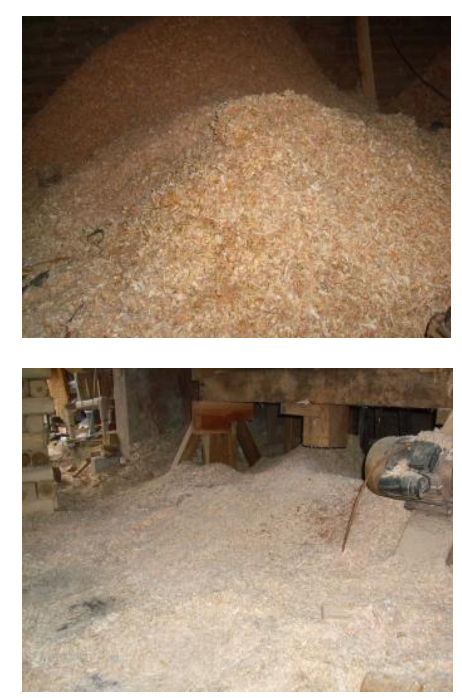

Figure. 1. Waste produced by the sawmill industry, sebetan (above) and sawdust (bottom)

\section{Research Method}

Some research on the utilization of waste wood powder as a reference of this research has been done a lot. Utilization of existing sawdust waste is: 1) Particle board where sawdust is united with glue to form a board; 2) Sawdust is processed into pulp for paper making; 3 ) In agriculture, sawdust can become mulch and mushroom growing media; 4) Sawdust can also be a liquid absorber, so that spilled liquids can be more easily cleaned [7]; 5) Sawdust as a briquette fuel that is nested. This utilization was first commercially performed by Henry Ford from sawdust and secondhand timber produced by his car factory. [8] 6) Cellulose can be extracted from sawdust. In the food industry, 
cellulose is a filler on various foods, so the volume of food looks bigger. Foods stuffed with cellulose from sawdust include sausage and bread. Cellulose from sawdust has also been used to become a sausage casing.

Based on some of the above research results, the research related to the waste of wood powder / sawdust is directed to the processing and utilization of wood powder waste into new materials that serve as supporting materials for furniture industry and possibilities for other industries such as crafts and interior accessories.

This research was conducted in Klaten and Boyolali. This area was chosen because they have many craftsmen furniture and crafts with wood base material. These areas include: Temu Wangi, Gombang, Karang Anom, Jatinom, Poker Ceper. This development is possible to widen in the area around the target object such as Sukoharjo, Boyolali, and Karanganyar, because they have the same potential. The location of experimentation related to the manufacture of Limbukyu formula is done in the laboratory of Indonesian Institute of Art Surakarta and craftsmen in Boyolali.

The focus of the research is directed to the making of Limbukyu formula and the development of design (Design development) [9] which includes: make material selections, select purchases items, select color and finishes. The visualization of furniture component design is directed to selling point and innovative (novelty on pattern and material) but still considering the Limbukyu character. In the creation of Limbukyu design required a design-breaking approach with experimental methods. Experiment is done by mixing various materials with certain composition in order to produce new material in accordance with the characteristics of furniture support materials. Therefore need a design strategy that is able to produce innovative work that packs all the standards that become market demands. Design that not only has a practical function, but loaded with artistic value, character, and cultural characteristics of the archipelago. The data source from the artifact [10] was used to determine the theme / character of Javanese furniture design. Literature is used to support the information related to the use of Limbukyu. Objects [11] in the form of materials / materials that will be used as experimental materials for furniture. The analytical technique uses inter-case analysis of various experiments to determine the material and design of furniture that match the character of the material and the design theme.

The results of the analysis is a basic foothold of the formulation of alternative designs which will then be determined the choice of one alternative as the design output that is ready to be tested. Furniture component experiments were tested in several furniture craftsmen. The results of trials from several cases in the craftsmen were then analyzed, evaluated for subsequent product refinement. The design of furniture is intended as an effort to create a model, frame shapes, patterns or patterns that are planned and designed according to the demands of human needs. [12] The design is directed to be able to answer the esteem needs, social needs, security needs, and physiological needs, then the design must pay attention to the human biological factors. Feldman divides artwork into three aspects: structure, function, style. [13] As Myers says "a good design usually suggests its function." [14] In addition to the aesthetic aspects of the function will be much involved because of its relationship to the craft design.

\section{Limbukyu Processing to Furniture Supporting Materials}

Wood has been used for centuries by humans as raw material for making houses, furniture, various kinds of handicrafts, and fuel energy. Until now, wood is still as the main raw material of national furniture products. In the process of processing wood into this product will produce waste, which in the form of sebetan, pieces of wood, tatal, and powder. Sebetan is the waste of wood processing log (logs) in the wood cutting industry into a component, such as boards and beams, rafters, battens and so forth. Cutting waste is the waste of wood in the production process due to the excess size of the required size. Tatal is a waste of wood produced from the production process due to the smoothing / flatting process. The sawdust is waste resulted at the time of making material and during production. This waste is the result of the remaining production, especially sawmill, both on the band saw machine, saw mill and bench saw.

\subsection{The Materials and Tools Needed}

As this research focus on the processing and reuse of Limbukyu as a material supporting furniture with environmentally friendly concepts, then as much as possible the selection of materials to be used is also environmentally friendly. The materials used in the process of making raw materials as furniture supporting material from Limbukyu, are as follows.

a. Sawdust yield of size about 80 mesh between $2.0-225 \mathrm{~kg}$.

b. White cement $1.25-1.5 \mathrm{~kg}$.

c. Calcium $1 \mathrm{~kg}$.

d. Water 0.8 - 2.0 liters.

e. White glue $1.25 \mathrm{~kg}$.

The composition of the various materials mentioned above with the main ingredient component is the waste sawdust, we call the term Limbukyu. Limbukyu is the main material, which is sawdust waste from sawmill industry. White cement and calcium serve as a catalyst for the dough to be solid, dry quickly and reduce the shrinkage of the ingredient mixture. White glue serves as a binder between the waste of sawdust and the catalyst. Water serves to thin the white cement and calcium also facilitate the mixing with sawdust. The need of the material mentioned above is a requirement of production with limited scale / small. As for production with large or mass capacity, the volume or quantity required is a multiple of the above list.

The evaluation of several experimental results of materials with various compositions shows that excessive sawdust produces a crumbly material. Similarly, the lack of white glue, the material easily broken due to lack of adhesive substances. The excess of white cement and calcium causes the material too heavy, hard, and reduce the nature of the wood. 


\subsection{The Processing of Limbukyu}

To obtain new material from the above ingredients component by mixing some of these materials with the following steps.

a. Mix or stir the white glue and water until smooth.

b. Mix simultaneously sawdust, white cement, and calcium.

c. Mix all the components in a baking sheet and add the water little by little while stirring.

d. Insert in the mold and press until solid so that there is no cavity so as to affect the strength of the printout.

e. Then dry in the sun, wait until dry between 5 - 6 hours.

After drying the material can be used as needed. If on one of the surface of the desired material is given a treatment, such as ornamentation, special texture, color and others, the surface can be reprocessed with the technique of carving / tatah and in finishing.

\section{Application of Limbukyu on Furniture Design}

Before Limbukyu applied to the furniture, the first step is to make a sketch of furniture design first. The design sketch is intended to determine the function, shape, material, construction, and type of finishing. Functions are directed at furniture for seating in eating and drinking activities. As an experiment, the shape of the design still leads to the conventional form of furniture, because it still has to consider the structure, materials, and construction. The main ingredients of this design are still using teak or mahogany material with Limbukyu support materials and materials for the holder of lurik fabric to show the character of Java. The main material is a material that serves to sustain and function as a structure / forming the furniture. Supporting materials are materials used to support the main material for furniture more functional, comfortable, and beautiful, such as leather, upholstery, vinyl, sponge, plywood, and so on. The main construction is used with conventional wooden connection techniques. Finishing using finishing water based raw materials with politure technique on main component. In the finishing support component allows to expose the texture of Limbukyu, ornamentation with the technique of tatah / carving, or by giving a certain color according to the theme. The design sketches being piloted are as follows.

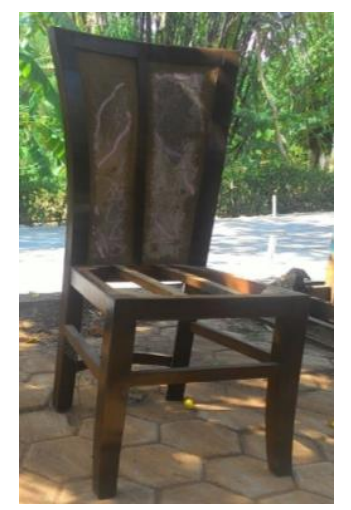

Figure 2. Application of Limbukyu for backbones chairs

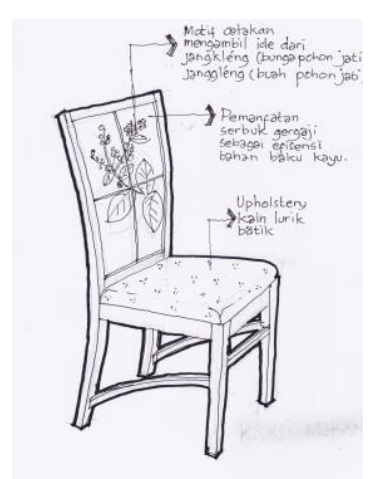

Figure 3. The sketch of chairs design for eating and drinking activities using sawdust supporting materials for backbones and upholstery of lurik fabrics

The design test is not only on the products of the chair for the eating and drinking activities but also tested to make the design of coffee table, frame of photo / mirror, standing lamp, wall lamp, and feature wall.

The advantages of using Limbukyu include: the material is available quite a lot and has not been utilized optimally, Limbukyu material is more adaptable, it means that it is easily formed according to the desired design. Having unique selling point for using materials that are rarely found in the market in general and used for design furniture and interior accessories which are special or unique. The main ingredients of Limbukyu are easy to find, they are cheap, easy to produce, lightweight, and environmentally friendly. With these advantages, the development of using sawdust is very promising, especially in the production of furniture and interior accessories, due to get cheaper production cost, with a more competitive sale price. The weakness of using Limbukyu materials include: materials can not be used directly (must be processed first), not resistant to water, in general Limbukyu formula is still produced on a small scale, when produced on a large scale requires additional equipment. Limbukyu formula production on a large scale is still very possible and affordable. Therefore, for further development there is a need for laboratory tests to ensure the stability of the composition / formula and the level of strength, durability, and safety of materials can be accounted for.

\section{Conclusion}

Basically waste of sawdust can be processed back into raw materials supporting the manufacture of furniture. Reprocessing of sawdust is necessary by adding / mixing other ingredients, such as: white glue, white cement, calcium, water and other possible ingredients. With certain formula will get new material from Limbukyu with good quality. Formula of this waste wood processing based on the characteristics can be used as material for making design work and other artworks. The use of Limbukyu for furniture design can be applied to the chair, top table, frame of photo / mirror, standing lamp, wall lamp, feature wall and still allow to be used in other furniture product and also for inte- 
rior accesories. The advantages of using Limbukyu include: the material is available quite a lot, Limbukyu material is more adaptable. Having a unique selling point because it uses materials that are rarely found in the market in general. The main ingredients of Limbukyu are easy to find, they are cheap, easy to produce, lightweight, and environmentally friendly.

\section{REFERENCES}

[1] http://kemenperin.go.id/artikel/10154/2015,-Ekspor-Furnitur -Ditargetkan-Capai-US\$-2,8-Miliar accessed $9^{\text {th }}$ August 2017, 12.05 WIB.

[2] waystoperfect.blogspot.com

[3] Anas Zaman, Biranul. How to Get Smart in the Arts Industry: Pursuit of Creative-Arts-Tourism Economy, Art College in the Creative Economy Era (Jurus Cendekia dalam Industri Seni: Menyiasati Ekonomi Kreatif-Seni-Pariwisata, Perguruan Tinggi Seni dalam Era Ekonomi Kreatif). Surakarta: ISI Press, 2012. p. 1

[4] Laurens, Jouyce Marcella Laurens. Architecture and Human Behavior (Arsitektur dan Perilaku Manusia). Jakarta: PT Grasindo, Anggota Ikapi, 2004. p. 100.

[5] Dharsono. Art Imagery: Creative Products in Higher Education Institutions Art as Capital / Assets to Build 'Brand Image'. Art College in the Creative Economy Era (Pencitraan Seni: Produk Kreatif pada Lembaga Pendidikan Tinggi Seni sebagai Modal/Aset untuk Membangun 'Brand Image". Perguruan Tinggi Seni dalam Era Ekonomi Kreatif). Surakarta: ISI Press, 2012. p.142.

[6] Zoest, Aart van. Semiotics (Semiotika). Jakarta: Yayasan Sumber Agung, 1993. p.1-5.

[7] Felman, David. "Why Did Bars Used to Put Sawdust on the Floor? Why Don't They Anymore?" Why Do Elephant's Jump? New York: HarperCollins, 2005. page 118, ISBN 978-0-06-053914-6, quoting Christopher Halleron, bartender and beer columnist.

[8] Green, Harvey. Wood: Craft, Culture, History Penguin Books, New York, 2006. page 403, ISBN 978-1-1012-0185-5 (As written on Http://id.wikipedia.org/wiki/istimewa:sumber buku/9781101201855)

[9] Pile, John F. Interior Design. New York: Harry N. Abrams, Inc., 1988. p.134-138.

[10] Soedarsono, R.M.. Research Methods for Performing Arts and Fine Arts (Metodologi Penelitian Seni Pertunjukan dan Seni Rupa). Bandung: Masyarakat Seni Pertunjukan Indonesia, 2001. p. 128

[11] Sutopo, H.B. Qualitative Research Methods: Basic Theory and Applied in Research (Metode Penelitian Kualitatif: Dasar Teori dan Terapannya dalam Penelitian). Surakarta: UNS
Press. 2002. p. 64.

[12] Marizar, Eddy S. Designing Furniture; Creative Designing Designing Techniques. Concepts, Solutions, Innovations, and Implementation (Designing Furniture; Tehnik Merancang Mebel Kreatif.Konsepsi, Solusi, Inovasi, dan Implementasi). Yogyakarta: Media Presindo, 2005. p. 17.

[13] Edmund Burke Feldman, Art as Image and Idea, New Jersey: Prencict Hall., Inc., 1967. p. 134.

[14] Myers, Bernard. The Doubleday Pictorial Library of The Arts, Man Creative Imagination. New York: Doubleday \& Company Inc., Garden city, Vol 7, 1965. p.128. 